\title{
PORTUS AND ROME'S MEDITERRANEAN PORTS PROJECTS
}

doi: $10.1017 / S 0068246217000289$

Our work at Portus, directed by Simon Keay and Renato Sebastiani, represents a continuation of our valued collaborations with the Soprintendenza Speciale per il Colosseo, il Museo Nazionale Romano e l'Area Archeologica di Roma and the University of Southampton. While we have decided to pause the Portus Fieldschool this year, in order to focus on the preparation for publication of the first volume of the Portus excavations (2007-11), we have been working closely with the Soprintendenza, the Parco Archeologico di Ostia Antica and the Centro di Conservazione Archeologica (Roma) in developing a project for the conservation of the excavated area of the Palazzo Imperiale, as part of a broader initiative to develop the tourist and educational potential of the site.

This and related issues were discussed at a well-attended workshop Research, Conservation and Fruition: a Project for the Palazzo Imperiale at Portus, which was held at the British School at Rome on 11 November 2016. Our collaborative work with the Soprintendenza and Parco Archeologico di Ostia Antica at Portus is benefiting from the very generous funding of two consecutive one-year post-doctoral fellowships by Peter J. Smith, which will be focused on undertaking research and public engagement research at the port, starting in the academic year 2017-18.

Aside from this, we have undertaken two geophysical surveys in the context of the third year of the European Research Council-funded Rome's Mediterranean Ports Project. The objective of the first was to clarify key questions relating to the exact position and character of the western end of the northern arm of the mole of the Claudian harbour and the pharos or lighthouse island; this is intended to enable us to understand better the properties and dynamics of the harbour, the precise function of which, in the context of the harbour system at Portus, is still the subject of debate. It should also enable us to draw analogies with other port sites in the project, most notably Tarraco (Spain), Ephesos (Turkey), Puteoli (Italy) and Utica (Tunisia), all four of which have been investigated by means of integrated suites of geophysics and geoarchaeological cores. The work was led by Sophie Hay of Archaeological Prospection Service of Southampton (APSS) and Stephen Kay of the BSR. By building on earlier work by Italian colleagues who established the approximate position of the mole with a programme of deep cores in a paper published in 2011 (Morelli, Marinucci and Arnoldus-Huyzendveld, 2011), we surveyed a large swathe of its supposed course with ground-penetrating radar. This revealed a number of possible alignments that are difficult to read, perhaps because the mole lies deeper than the $c .6 \mathrm{~m}$ that we suspected, or because the radar signal was attenuated on account of the water table or the salt content of the soil. We plan to calibrate these results in 2017 with a programme of electrical resistance tomography, which will allow anomalies to be plotted to a depth of $c .15 \mathrm{~m}$, and geo-archaeological cores.

The second geophysical survey was undertaken at Utica. A team from Geocarta SA, led by Michel Dabas and Jean-Marc Valet, conducted the survey. The gradiometer survey continued previous work (Hay et al., 2010; Ben Jerbania et al., 2015; Maw, 2015) in the southeastern quarter of the site, which had revealed the presence of about 70 insulae blocks arranged on an orthogonal street grid. 
The latest results, covering an area of about 22 hectares, complemented these findings, and the regular pattern of the city's layout clearly extends towards the ancient course of the Medjerda river. The survey demonstrated that the dimensions of the insulae are a consistent $80 \times 40 \mathrm{~m}$, and confirmed that the city is notably larger than previous estimates (Lézine, 1968: fig. 1). Although the walled divisions of many of the insulae can be identified, other blocks seem to have more open spaces inside. This could indicate a less dense pattern of occupation, and suggests that the unified layout of the late second-century $\mathrm{BC}$ city may have exceeded demand. At the same time, some of this detail may not show because the depth of the overlying deposit increases towards the southeast of the site. A core sample taken at the extreme southeastern limit of the gradiometer survey demonstrated that up to $6 \mathrm{~m}$ of material has accumulated over the archaeological remains (Pleuger et al., 2014: 14) and for this reason even the traces of the roads in the results for this area appear faint.

Two discrete outlying buildings were detected in the results. Neither of these complexes appears to lie on the same orientation as the existing urban plan, suggesting they could be later than the conception of the city or simply lie beyond its boundaries.

The results of this highly collaborative international project were disseminated at a third international conference at the BSR in January, with participants from the BSR, the University of Southampton, the University of Oxford, the Universite La Lumière Lyon 2, the Deutsches Archäologisches Institut (Istanbul), the Österreichisches Archäologisches Institut, the Institut Català d'Arqueologia Clàssica, the Universität zu Köln, the Universidad de Cádiz, the Italian Soprintendenza for Rome and many others.

\section{References}

Ben Jerbania, I., Fentress, E., Ghozzi, F., Wilson, A., Carpentiero, G., Dhibi, C., Dufton, A., Hay, S., Jendoubi, K., Mariotti, E., Morley, G., Oueslati, T., Sheldrick, N. and Zocchi, A. (2015) Excavations at Utica by the Tunisian-British Utica Project 2014. On-line publication: https:// www.academia.edu/12718443/Excavations_at_Utica_by_the_Tunisian-British_Utica_Project_2014

Hay, S., Fentress, E., Kallala, N., Quinn, J. and Wilson, A. (2010) Utica. Papers of the British School at Rome 78: 325-9.

Lézine, A. (1968) Carthage. Utique. Études d'architecture et d'urbanisme. Paris, Centre National de la Recherche Scientifique.

Maw, E. (2015) Utica. Geophysical survey report. Unpublished report.

Morelli, C., Marinucci, A. and Arnoldus-Huyzendveld, A. (2011) Il porto di Claudio: nuove scoperte. In S. Keay and L. Paroli (eds), Portus and its Hinterland (Archaeological Monographs of the British School at Rome 18): 47-65. London, British School at Rome.

Pleuger, E., Abichou, H., Gadhoum, A., Goiran, J.-P., Quinn, J., Fentress, E., Wilson, A., Ben Jerbania, I. and Fagel, N. (2014) Paléoenvironnement et géoarchéologie du delta de la Medjerda. Unpublished report.

Simon Keay and Sophie Hay (Faculty of Humanities, Archaeology, University of Southampton / British School at Rome; Archaeological Prospection Service of Southampton) sjk1@soton.ac.uk; s.a.hay@soton.ac.uk 